\title{
The Influence of CSR Awareness on Consumer Behavior Through Trustworthiness: The New Approach
}

\author{
Zohreh Alizadehrad $^{1 *}$ and Ekaterine Maglakelidze ${ }^{2}$ \\ ${ }^{1} \mathrm{PhD}$ Student at the University of Georgia (UG), School of Business, Economics and \\ Management, Georgia \\ ${ }^{2}$ Associated Professor at the University of Georgia (UG), School of Business, Economics \\ and Management, Georgia
}

\section{ARTICLE INFO}

\section{Keywords:}

CSR

CSR Awareness

Corporate Credibility

Corporate Trustworthiness

Purchase Intention

Customer Involvement in CSR

Activities

Descriptive Research

Customer's Inclination to

Purchase Products

\begin{abstract}
The goal of this research is to measure the level of customer awareness of Corporate Social Responsibility (CSR) in Georgian society and to study the influence of CSR awareness on consumer behavior through trustworthiness (one of the dimensions of corporate credibility) by revealing the correlations between customer awareness and corporate trustworthiness, customer willingness to be involved in CSR initiatives and customer purchase intentions. The descriptive research was carried out and data were collected based on the survey of 915 respondents located in Tbilisi, Georgia. The relationships between variables have been studied by using multiple regressions technique. This article provides data that lead to a new conceptual model and point the importance of elevating the level of customer CSR awareness in achieving corporate credibility goals.

Beyond it, customers' inclination to purchase products from those companies who care about their long-term interest has been revealed.
\end{abstract}

\section{Introduction}

Corporate Social Responsibility (CSR) is nowadays part of the recent agenda for public policymakers. Some marketing experts believe consumers are increasingly using their perceptions of a firm's role in society in their purchase decisions. For example, consumers want to know how a firm treats its employees, shareholders, local neighbors, and other stakeholders or constituents. As the head of a large ad agency put it: "The only sustainable competitive advantage any business has, is its reputation." Among the different stakeholders addressed by CSR, consumers stand for the large economic impact and diversity of assessing effects. Prior literature on CSR and consumers tested the effect of CSR on corporate credibility (Brammer \& Millington, 2005; Lichtenstein, Drumwright, \& Braig, 2004) emphasizing that one of the key elements in any CSR research should be how corporations report consumers' perception of CSR. Otherwise, no matter what kind of CSR practices implemented by companies or how CSR initiatives engage in, the impact of CSR on consumer behavior may be null or even negative (Du, Bhattacharya, \& Sen, 2010). With the rising practical application of CSR, the question of how to convey related messages to positively impact customers is growing in importance.

\footnotetext{
* Corresponding author E-mail address: alizade.zohre@gmail.com 
Corporate credibility is a particularly important set of abstract associations that measures the extent to which consumers believe a firm can design and deliver products and services that satisfy their needs and wants. It is the credibility the firm has achieved in the marketplace and consumers who perceive the brand as credible, is more likely to consider and choose it. A strong and credible credibility can offer additional benefits. However, the relationship between CSR initiatives and corporate credibility has been scarcely investigated and consequently, our understanding of the disaggregated drivers and causes of corporate credibility is incomplete.

In Georgia, as a developing country, CSR does not have a long history and this field is not studied well. In the face of growing attention to corporate social responsibility (CSR) activities in the marketplace, this paper seeks to demonstrate the level of CSR awareness in Georgian society. Since the concept of corporate social responsibility in Georgia is relatively new in all sectors of economy, there is hardly any data available on the level of customer satisfaction and/or customer trust toward the companies who practice CSR. In fact, there is no previously conducted research available, at least in the public domain. To fill in this gap, this descriptive research was undertaken for the purpose to measure customer CSR awareness as well as to describe customers' attitudes toward the companies practicing CSR, and it is all done for answering the research questions defined as below:

Q1: Does Customer awareness of company CSR activities lead to more company trustworthiness?

Q2: Does Customer awareness of company CSR activities encourage customer to be engaged in CSR initiatives?

Q3: Are CSR aware customers more inclined to purchase products from those companies who care about their long-term interest (healthy food, healthy environment and etc.)?

Q4: Does customer awareness of company CSR activities lead to higher level of purchase intention?

\subsection{Value of the Data}

Research outcomes explain the ways how CSR awareness influences consumer behavior, which can direct other analysts toward planning comparative models for extending examinations in this setting. Proposed research questions can be used as a springboard to define a comprehensive CSR strategy in companies in different domains. They shall, therefore, facilitate further studies on this field of research. Researchers can utilize data inside this article as comparison materials with other data gotten from other businesses, cities, locales, or nations. For future studies, scholastics can utilize the questionnaire. It is an approved tool, so it can be applied for other data.

The research adopted a survey research approach to obtain data from 915 respondents through a structured questionnaire that contains Likert scales and control questions. The questionnaire, which gives data on how the factors were measured, can be counseled within the supplementary record.

\section{Research Methodology}

The descriptive research conducted to measure customer demographics, CSR awareness, correlations between customer awareness and corporate trustworthiness, customer willingness to be involved in CSR initiatives and customer purchase intentions in Tbilisi, Georgia. In a review of methodologies utilized for CSR research, Taneja et al. (2011) found 
an generally inclination for quantitative approaches when testing cause-effect relations to move forward the validity of built up theories relating to CSR. Besides, the utilization of structured questionnaires has ended up prevalent among CSR analysts. Few analysts (e.g., Berens et al. 2007; Brown and Dacin 1997; Sen and Bhattacharya 2001) have utilized an experimental research design to check the affect of CSR initiatives on consumers as quantitative study that is valuable in surveying relationships between factors (Punch 2003). This methodology gives the analyst the opportunity of testing the conceptual framework of Du et al. (2007).

The descriptive research incorporates two fundamental stages. Within first stage, a survey questionnaire was outlined and a pilot test conducted. In the $2^{\text {nd }}$ stage of research, the survey was conducted on a large sample of population under study.

Main questionnaire carries 29 questions and uses the different measurement scales to measure the various constructs. Among them is a five-point Likert scale (ranging from 1= "completely disagree" to $5=$ "completely agree") that includes 24 researcher-made statements.

The questionnaire includes five sections: (1) assessing customer CSR awareness; (2) assessing corporate trustworthiness from customers' point of view; (3) assessing customers' willingness to be involved in CSR activities; (4) assessing customers' purchase intention; (5) customers' background characteristics.

Table 1.

The Composition of Questionnaire

\begin{tabular}{lll}
\hline Sections & $\begin{array}{l}\text { Number } \\
\text { Related questions }\end{array}$ & Qf \\
\hline $\begin{array}{l}\text { Assessing customer CSR awareness } \\
\text { Assessing corporate trustworthiness from Number }\end{array}$ & 11 & Questions: 1 to 11 \\
$\begin{array}{l}\text { customers' point of view } \\
\begin{array}{l}\text { Assessing customers' willingness to be } \\
\text { involved in CSR activities }\end{array}\end{array}$ & 5 & Questions: 12, 13, 14, 15, 16 \\
$\begin{array}{l}\text { Assessing customers' purchase intention } \\
\text { Customers' background characteristics }\end{array}$ & 4 & Questions: 17, 18, 19, 20 \\
\hline
\end{tabular}

The survey instrument was pre-tested during a pilot stage with an open-ended option, where 30 personal interviews were conducted among various demographic groups. Issues related to comprehension of difficult English words and use of complex sentence structure were found (Collins, 2003) and resolved by replacing them with easily understood words and phrases.

To make sure that the questionnaire captures what it is assumed to measure, the content validity and scale reliability methods were used. As to the content validity, the quantity and quality of questions were studied by experts. The scales' reliability was measured in two ways: through the analysis of Cronbach's alpha (numerical value of 0.5 is considered appropriate to show consistency) and through the composite reliability indices (IFC). [In all cases Cronbach's alpha is more than 0,5]

After piloting stage, a descriptive research was conducted on a large sample group. The data were collected by using online-survey of the population under study. The population under study is people living in Tbilisi, Georgia. For selection of respondents, the convenience sampling method was used. It should be noted that in January of 2020, 915 questionnaires were distributed among which 870 were returned and 862 were used for analysis.

After examining measurement scales and assessing their validity using confirmatory factor analysis, the relationships between variables have been studied. 
Table 2.

Variables, Measures, Codes and Scales' Reliability

\begin{tabular}{|c|c|c|c|c|c|c|}
\hline Construct & Mean & SD & $\begin{array}{l}\text { Factor } \\
\text { loadings }\end{array}$ & $\begin{array}{l}\text { Cronbach's } \\
\text { alpha }\end{array}$ & $\begin{array}{l}\text { Composite } \\
\text { reliability }\end{array}$ & $\begin{array}{l}\text { Average variance } \\
\text { extracted (AVE) }\end{array}$ \\
\hline Customer's CSR awareness & 4.58 & 1.85 & 0.90 & 0.95 & 0.95 & 0.76 \\
\hline Corporate Trustworthiness & 4.23 & 1.87 & 0.86 & 0.96 & 0.94 & 0.72 \\
\hline $\begin{array}{l}\text { Customer's willingness to be involved } \\
\text { in CSR activities }\end{array}$ & $d_{4.37}$ & 1.90 & 0.81 & 0.93 & 0.92 & 0.71 \\
\hline $\begin{array}{l}\text { Customer's inclination to Long-term } \\
\text { needs and Short-term needs }\end{array}$ & $\mathrm{n}_{5.89}$ & 1.49 & 0.73 & 0.86 & 0.87 & 0.63 \\
\hline Purchase intention & 6.58 & 0.78 & 0.61 & 0.73 & 0.77 & 0.63 \\
\hline
\end{tabular}

Table 3.

Data characterization

Demographic profile of respondents

All respondents $(\mathrm{n}=862)$

\begin{tabular}{lll}
\hline & Characteristics & Percentage \\
\hline \multirow{6}{*}{ Gender } & Male & $40.7 \%$ \\
& Female & $57.8 \%$ \\
& $20-29$ & $54.6 \%$ \\
& $30-39$ & $30.6 \%$ \\
& $40-49$ & $10.5 \%$ \\
& $50-59$ & $4.3 \%$ \\
& & \\
Education & High school & $3.6 \%$ \\
& Diploma or equivalent & $8.6 \%$ \\
& Bachelor's degree & $50.3 \%$ \\
& Master's degree or higher & $36.0 \%$ \\
& & \\
& Students & $34.9 \%$ \\
& Government officer & $5.9 \%$ \\
& Private employee & $43.5 \%$ \\
& Business & $6.8 \%$ \\
& Trade & $3.7 \%$ \\
& General Contract & $5.2 \%$ \\
\hline
\end{tabular}

The demographic profiles of respondents have been studied in terms of their gender, age, educational level, and occupation in order to assess the representativeness of the sample.

In keeping with the study objectives, the scale measuring CSR awareness had an 'NA' (Not Aware) option to screen out those respondents that lack of familiarity with the concept of CSR and had missing values on the key variables $(n=53)$. As a result, the initial number of respondents was reduced from 915 to 862 .

Gender distribution of the 862 respondents was almost equal with females (57.8\%) and males $(40.7 \%)$. Approximately half $(54.6 \%)$ of the respondents were twenty-nine years of age or younger. Furthermore, $50.3 \%$ of respondents were educated to the level of a Bachelor's and $30.6 \%$ of them have Master's degree or higher. In terms of occupation, $43.5 \%$ of respondents were private employees, followed by $34.9 \%$ students. This may reflect the fact that the data were mostly collected from universities and organizations in Tbilisi, Georgia. 


\section{Survey Results}

General familiarity with the term of CSR

1.What is level of your knowledge regarding Corporate Social Responsibility?

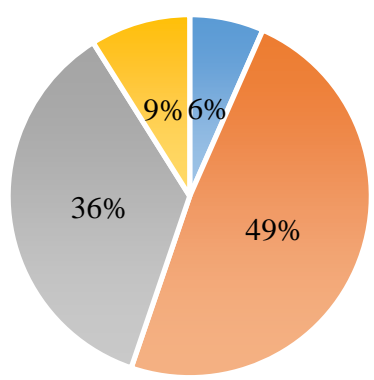

I do not know what it is

- I have basic understanding about this concept

- I am familiar with corporate social responsibility topic

Figure 1.

Source: Survey Materials

2.To be more precise, what does "Corporate Social Responsibility" mean to You?

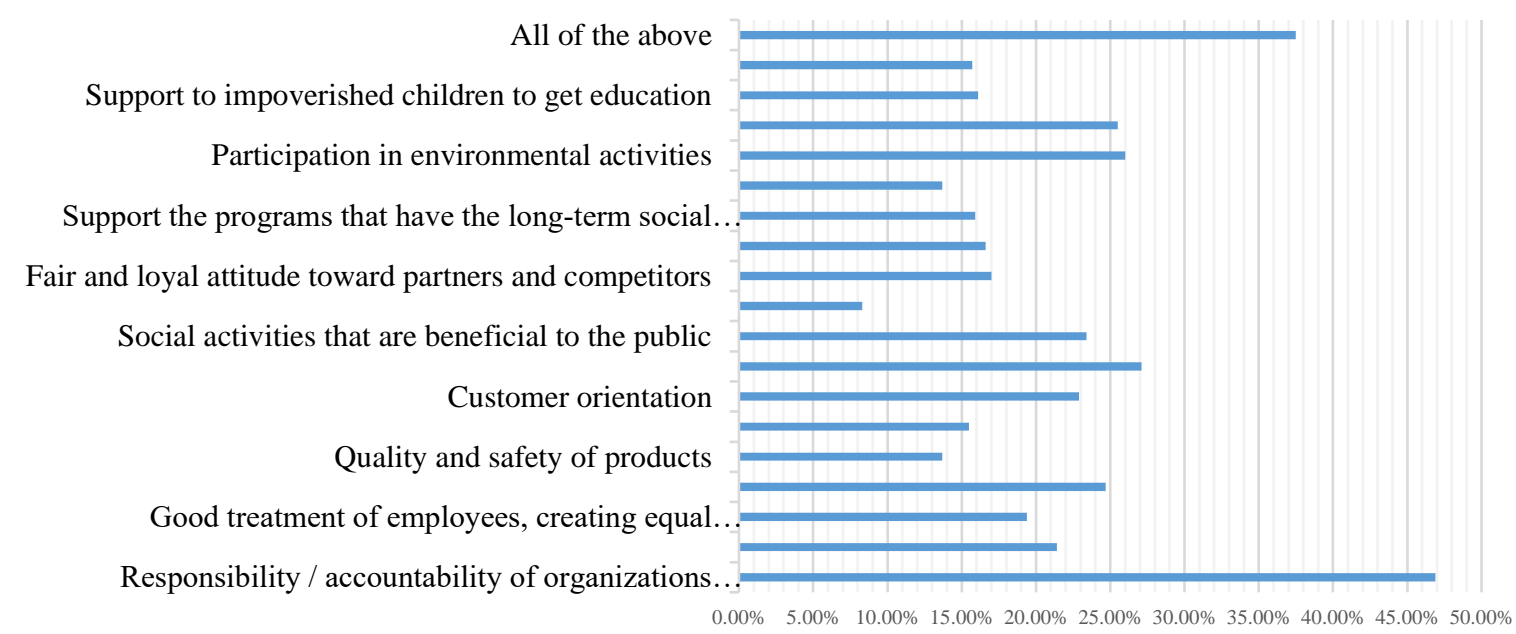

Figure 2.

Source: Survey Materials

As it is depicted in the figures above, $49 \%$ of the respondents have basic understanding about CSR and 36\% are familiar with this concept. Based on Figure 1, respondents are familiar with the term of CSR and could identify the CSR activities of particular brands or companies. For $46.9 \%$ of respondents CSR is a responsibility/ accountability of organizations toward society, $50,7 \%(24,7 \%+26 \%)$ perceives CSR as company's ecological responsibility (energy efficiency, recycling and etc.) and its participation in environmental activities, and only $37.5 \%$ of respondents cite CSR as a mixture of all mentioned items. Percentage distribution presented in the above graph indicates that almost $50 \%$ of respondents' relate CSR to social issues while $37.5 \%$ of respondents consider CSR as a comprehensive concept. This last result also serves as an additional prove to the responses obtained from the first question that $36 \%$ of respondents are familiar with, and $9 \%$ is well versed in CSR concept. Based on the different responses obtained from the different questions one can argue that for around $47,3 \%$ to $54 \%$ of respondents corporations social responsibility is linked to the environmental aspects and there is not apparent difference 
between corporations social and environmental issues and hence, these two are extremely interwoven.

3. Which of these reflects your understanding of CSR? (More than one choice possible)

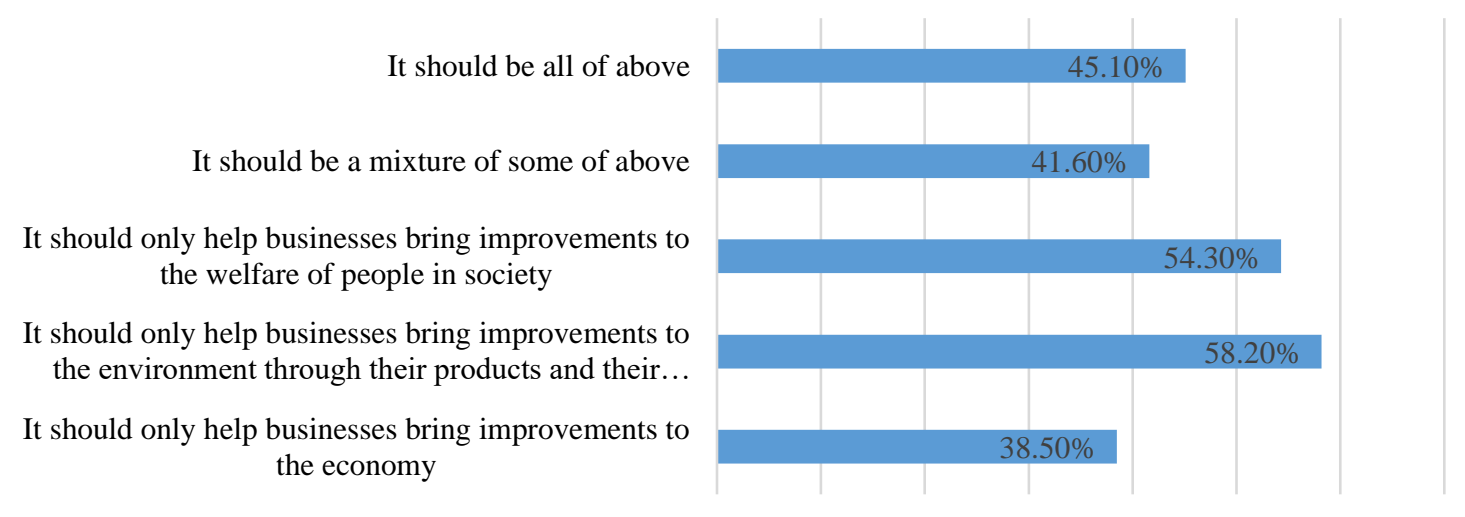

Figure 3.

Source: Survey Materials

The answers to the 3rd question serve as an additional prove to the above findings that for the majority of respondents $(58,2 \%)$ CSR is related to the improvement of environment. Accordign to the percentages showed in the figure 3, one can say that, although the respondents are aware of the term of CSR, they relate CSR to more environmental aspects. May be it is because the corporations are more heavily advertising that very aspects of thier CSR activities in relation to others.

4.How much attention do you pay to Corporate Social Responsibility policy of a company as a customer?
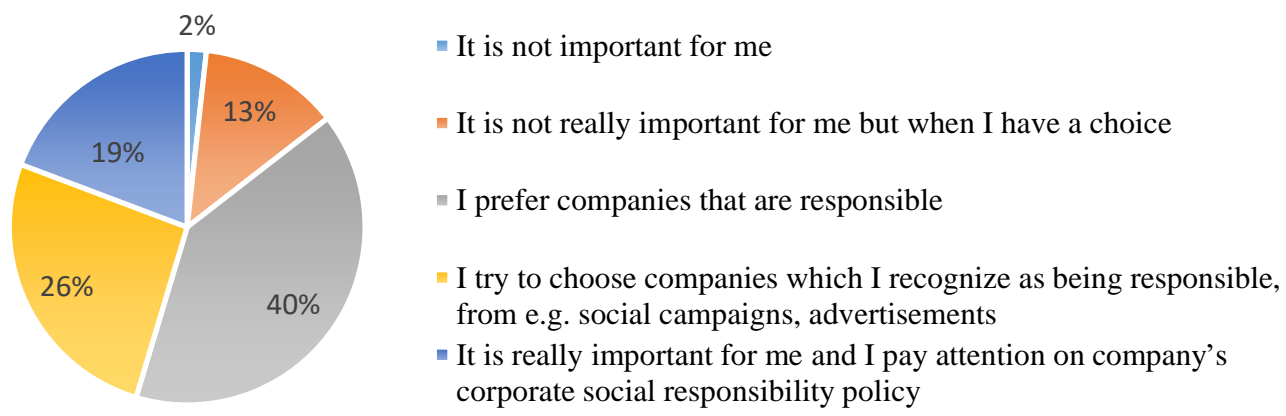

Figure 4.

Source: Survey Materials

As it is obvious from the above histogram, $40 \%$ of respondents prefer companies who are responsible for CSR activities. Obtained results demonstrate that CSR can be a determining factor for choosing a product. 
5. How much attention do you pay to Corporate Social Responsibility policy of a company as an employee?
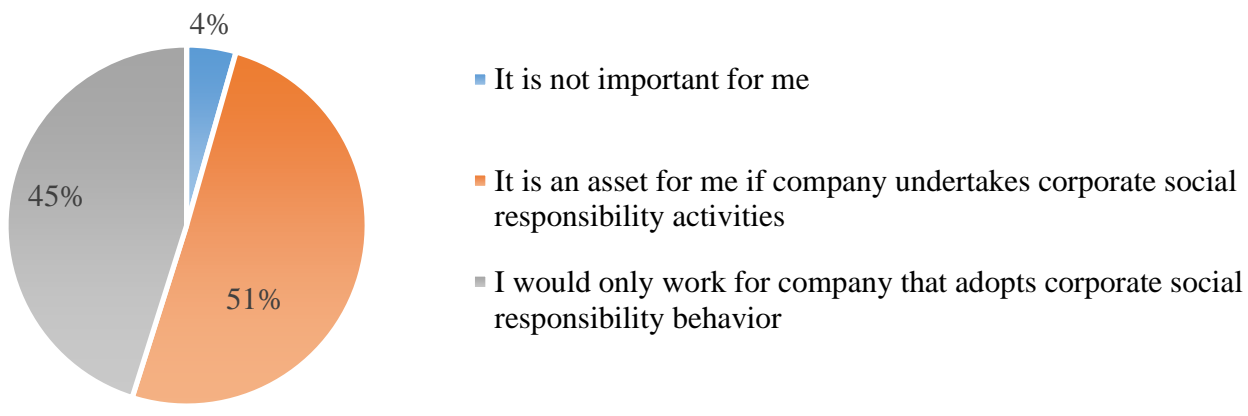

Figure 5.

Source: Survey Materials

Based on the answers to the question \#5, 51\% of respondents perceive CSR as an asset for them and $45 \%$ would work only for a company that adopts CSR. This amount of attention among respondents when choosing a company to work with obviously indicates the high amount of importance of this notion among them.

6. CSR can be "Voluntary" or "Regulated". Which of the two approaches do you consider more suitable?

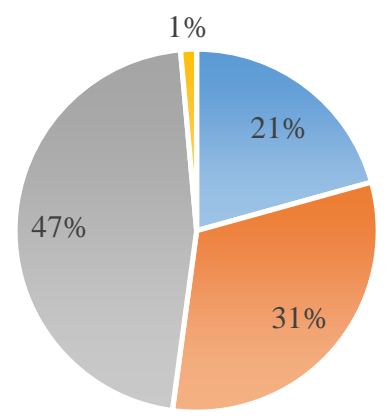

- Voluntary approach (that is, companies are/ should be left alone to do what they consider best as CSR)

- Regulated approach (that is, the Laws of each country specifying the particular responsibilities owe to society)

- I think both approaches are necessary

" None of the above

Figure 6.

Source: Survey Materials

Based on the study results obtained as a response to the question \#6, 47\% of respondents believe that both approaches (voluntary as well as regulatory) are neccesary when making decisions about CSR initiatives. That means that to some extent the corporations should be left alone to do what they consider best as CSR but the government should also enact laws which pushes companies to exercise CSR as an integral part of their daily activities and that annual CSR report should be available to public on their websites as the main source of information about company's CSR activities. 
7. How often have you discussed any company's behavior with someone during the past 6 months?

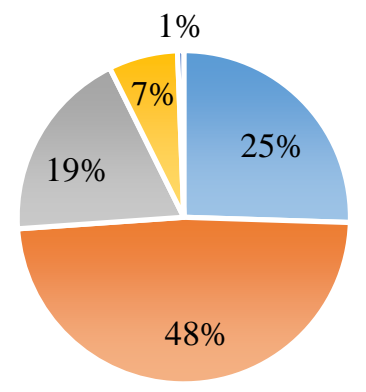

$$
\begin{aligned}
& \square \text { Many times } \quad \square \text { A few times } \\
& \square \text { Hardly at all } \quad \square \text { Not at all } \\
& \square \text { I don't remember }
\end{aligned}
$$

Figure 7.

Source: Survey Materials

The answers to the question \#7 revealed that $48 \%$ of respondents have disscused comapnies ${ }^{6}$ behavior toward society with others a few times. It appears that despite of low level of CSR awareness among customers, the companies' level of influence on the society can not be neglected or just overlooked. It is obvious that customers judge comapny's behavior and they share their opinions about them with other members of society.

4. What Aspects of Corporate CSR Have You Discussed With Your Friends or Relatives During the Past Six Month?

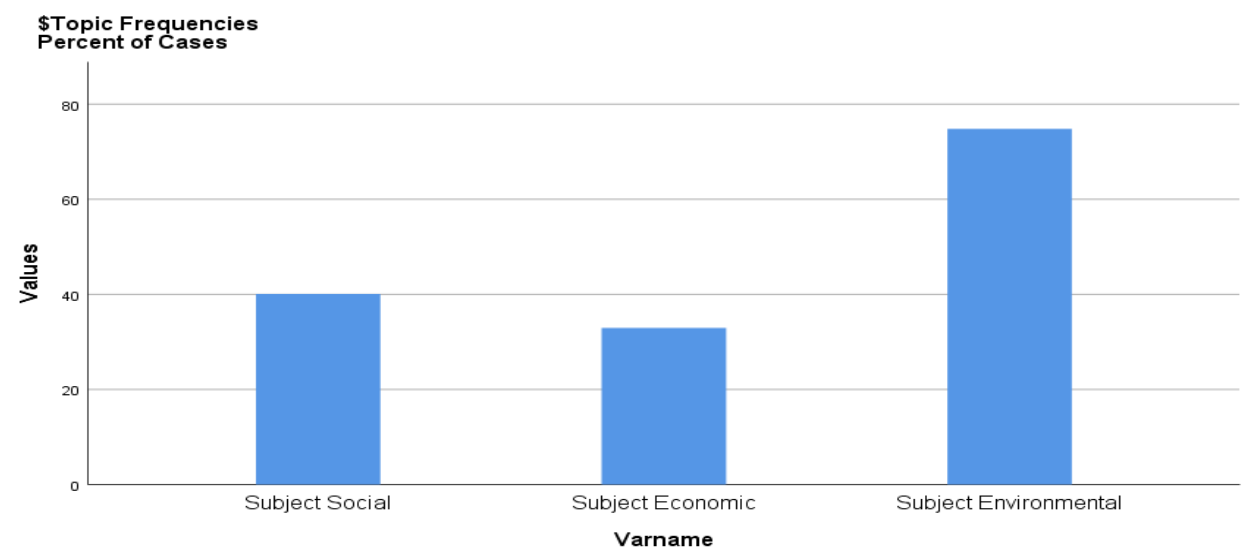

Figure 8.

Source: Survey Materials

Based on the answers obtained from the question \#8, 74.8\% of respondents discussed environmental aspects of corporate CSR with their friends and relatives during the past six month. That means that respondents consider environmental initiatives as one of the most important aspects of corporate social responsibility (CSR). Thus, one can conclude that for the majority of respondents' corporations CSR initiatives must be devoted only to the care about the environment, or to resolving only the social or economic issues of the society without understanding their integrity. It is not amazing at all because in Georgia, CSR concept isrelatively new and the deep comprehension for CSR does not exist in the society yet. 
9. What CSR activities are You aware the companies are engaged in?
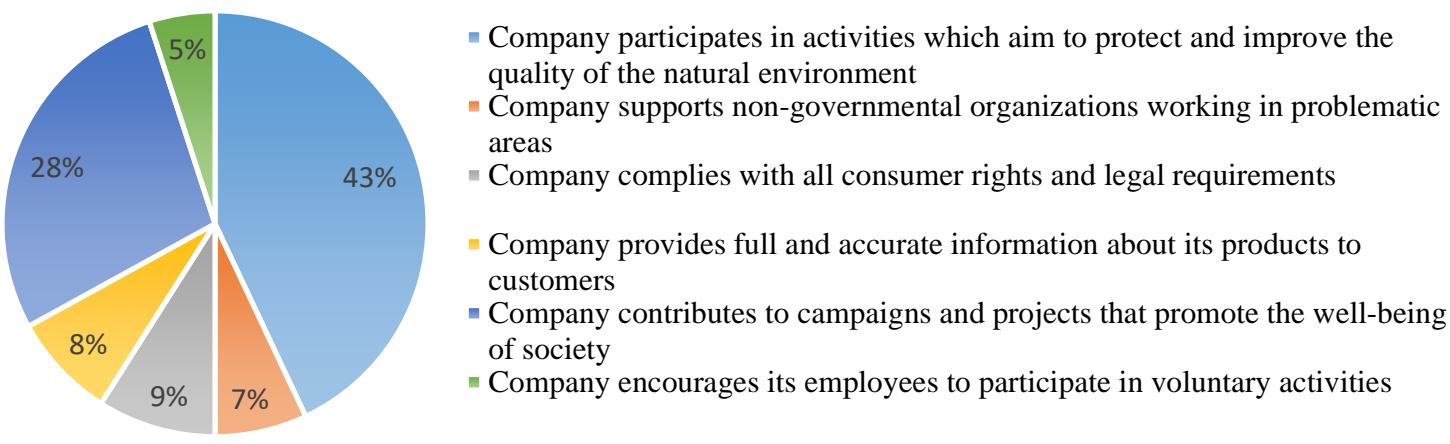

Figure 9.

Source: Survey Materials

The above pie chart related to the question \#9 shows that $43 \%$ of respondents are aware of corporations environmental activities and $28 \%$ of them are aware of thier social activites . These findings also support what we have already found in the survey above (see responses to the questions \#2 and 3). Besides, it is clear from the figures obtained that customers are not well aware of thier rights recieving the full and accurate information about products offered by the corporations (only $8 \%$ of respondents know about it). Moreover, only $9 \%$ of respondents perceive the complience with all consumers rights and legal requirements as the integral part of CSR initiatives. As long as members of a society are not aware of their rights in companies and also the responsibilities that corporations have towards them, this society will stay away from sustainable development.

10. What are your main sources of information about corporate CSR activities?

(Possible to choose more than one answer)

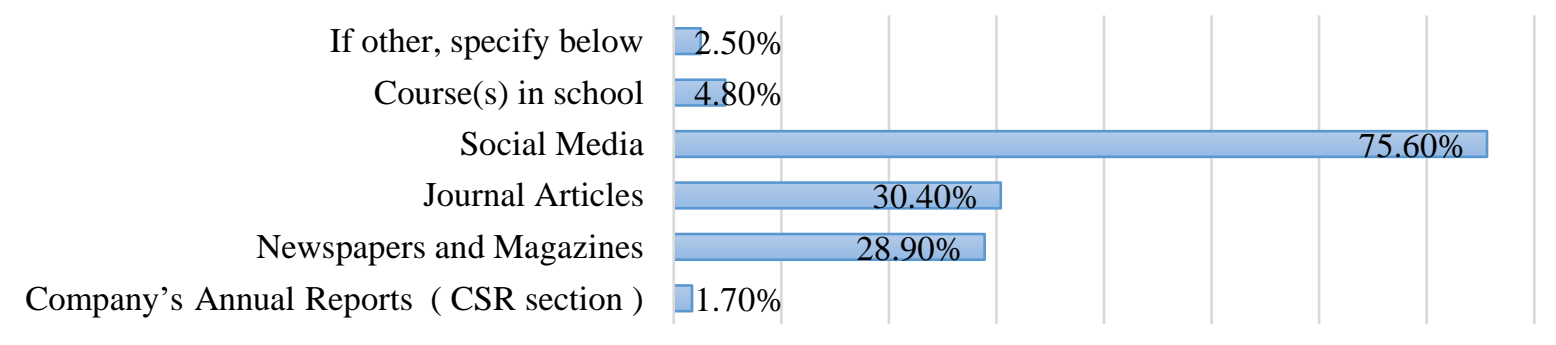

Figure 10.

Source: Survey Materials

The main source for the majority of respondents (75.6\%) to get the information about corporates' CSR initiatives, is a social media; corporations' annual reports (CSR section) as a source of information about their CSR initiatives has the lowest percentage, around 1.7\%. The results show that in Georgia, CSR sections of different corporations are not active enough. Corporations still fail to present their annual CSR reports to the public for their evaluations and approval. CSR course in school is less than 5\%. That means that universities and organizations must employ more workshops to increase society awareness towards CSR. Even it is suggested that for having a sustaibable society through CSR activities, companies should start from schools and kids for making CSR as a culture among the next generations. 
11.Do You trust the companies with such special activities? (two possible answers: Yes, No).

Company encourages its employees to participate in voluntary activities

Company contributes to campaigns and projects that promote the well-being of society

Company provides full and accurate information about its products to customers

Company complies with all consumer rights and legal requirements

Company supports non-governmental organizations working in problematic areas

Company participates in activities which aim to protect and

improve the quality of the natural environment,...

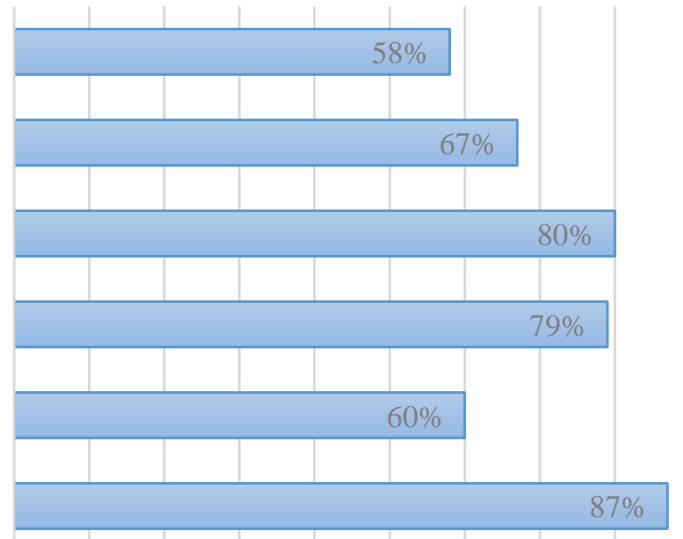

Figure 11 .

Source: Survey Materials

As it was expected, $87 \%$ of respondents exhibit their trust towards the companies that initiate the activities aiming at protecting and improving the quality of the natural environment, particularly, energy efficiency and recycling because they still relate the corporations social responsibility mostly to the care of environment;

12. How much do you trust the companies with such special activities?

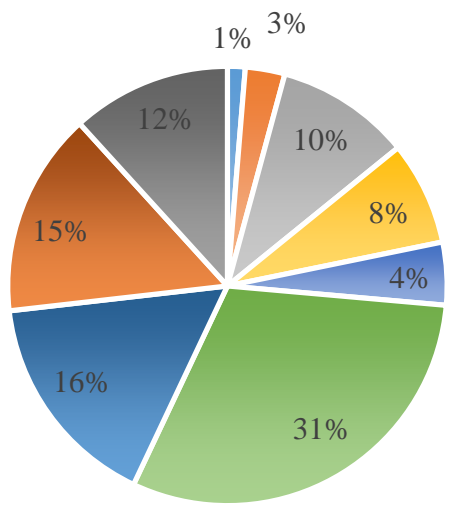

$=$ Neutral
$=$ very low trust
$=$ low trust
$=$ a little trust
$=$ neither trust nor non-trust
$=$ to some extant trust
$=$ trust
$=$ Well trust
$=$ High trust

Figure 12.

Source: Survey Materials

Answers given to the question \#12 show that $31 \%$ of respondents to some extent trust the companies that deploy the various CSR activities. 
13. In your opinion, to what extent do the companies with such special activities are aware of your needs?
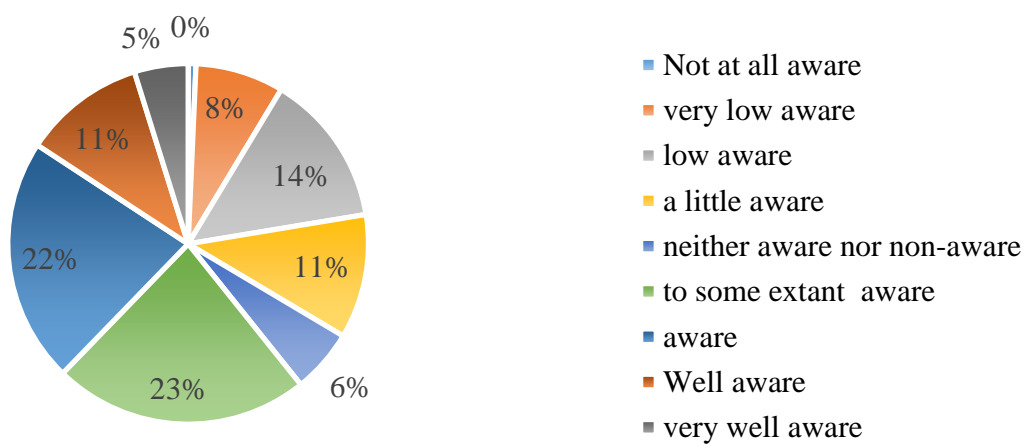

Figure 13.

Source: Survey Materials

Being aware of customers' needs is one of the main factors that can make a firm competitive in the marketplace. Therefore, it is necessary to measure the extent to which respondents believe that companies are aware of the needs of customers they serve. According to the responses to the question \#13, this is an issue which should be addressed more carefully by the corporations.

14. To what extent do the companies with such special activities consider your opinions?
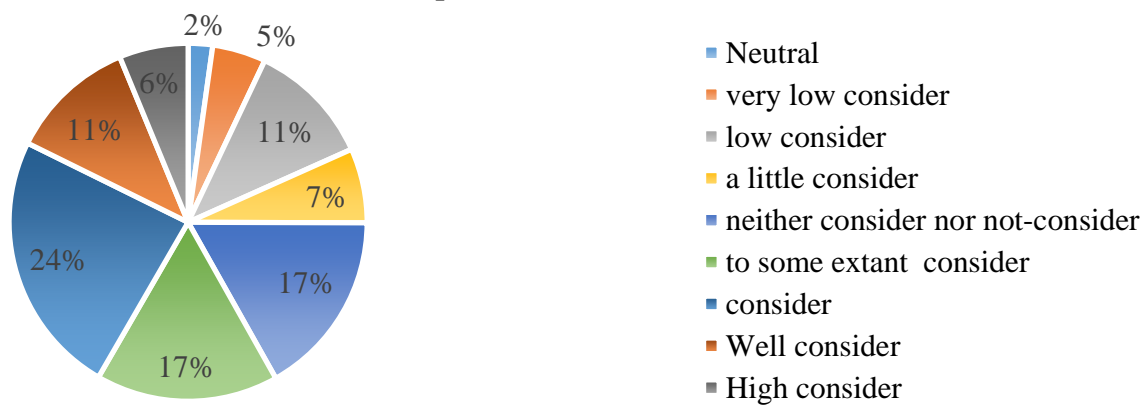

Figure 14.

Source: Survey Materials

Taking into account customers' opinions, is a crucial factor for corporations to grow further. Based on what is found in the survey, $35 \%(24 \%+11 \%=35 \%)$ of respondents believe that companies consider their opinions when planning CSR activities while 17\% believe that companies consider their opinions only to some extent. If generalizing the study findings to the total population using $95 \%$ confidence interval, around $41 \%$ of population believes that companies consider customer's opinions when planning their CSR activities. The variability in the sample is high enough that allows us to say that corporations CSR activities do not perfectly match the expectations of customers they serve. 
15. Are you engaged in corporate social activities?

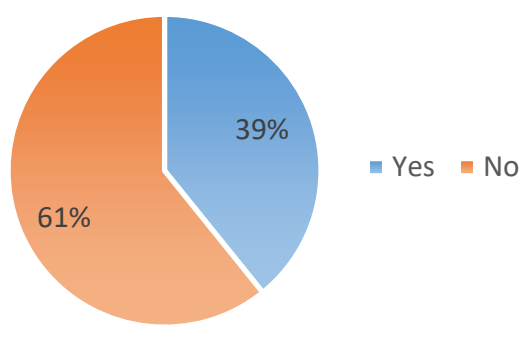

Figure 15.

Source: Survey Materials

As it was expected, $61 \%$ of respondents are not engaged in CSR activities. That's why they don't have the clear understanding of corporations' responsibilities toward them. If corporations want their customers to believe that they truly care about their long-term interests, customers should be involved in the process of planning CSR activities. Only in this way, customers can be quite confident that corporations are not spending their money only for endorsement purposes.

16. Which corporate CSR activities are You engaged in?

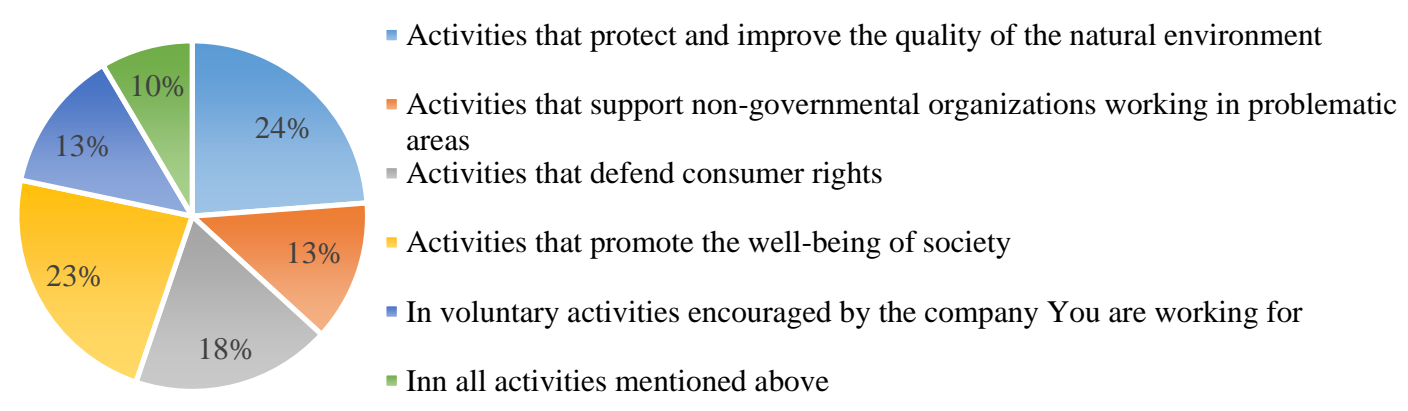

Figure 16.

Source: Survey Materials

From $39 \%$ of respondents who declared that they are engaged in CSR activities, $24 \%$ of them are involved in environmental activities and $23 \%$ with the same rate, have participated in social activities. It appears that social and environmental activities among the other CSR initiatives have been more welcomed or perhaps have been more invested by companies. $13 \%$ of respondents are employees who voluntarily participated in CSR activities that have been defined by the company they are working for. Data obtained testify that the minority of corporations that practice CSR do not create enough motivations for their employees to persuade them to be engaged in the socially useful activities. 
17. I am positive towards involving in CSR activities of the company engaged in CSR.

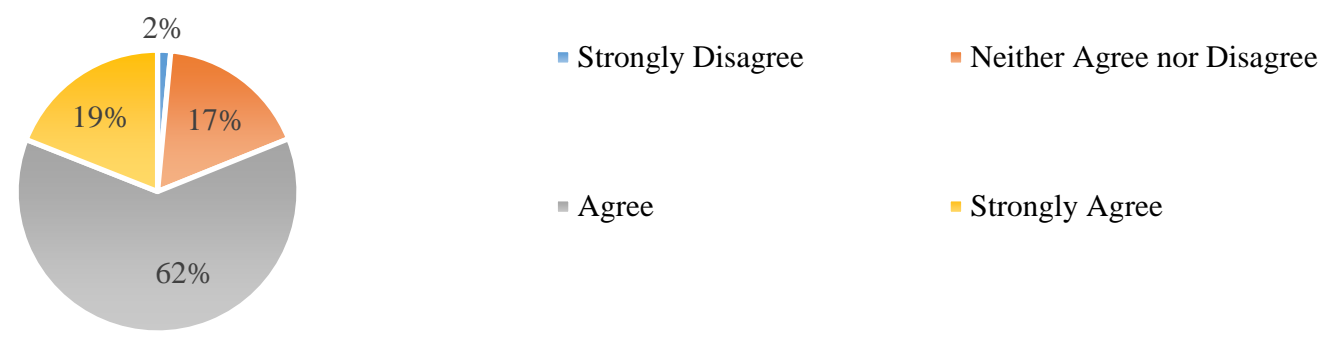

Figure 17.

Source: Survey Materials

According to the answers to the question \#17, the results obviously revealed the strong desire of respondents to be involved into social initiatives of the companies they work for. This is a positive outcome for a society moving toward sustainable development.

18. How likely are You to be engaged in CSR initiatives of the companies that practice CSR?

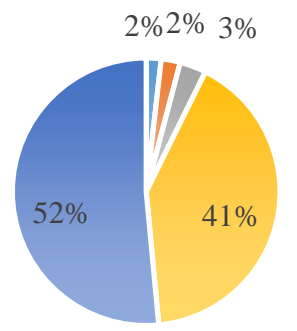

- Very Unlikely

- Unlikely

- Neutral

- Likely

- Very Likely

Figure 18.

Source: Survey Materials

The majority $52 \%$ of respondents expressed their readiness to be engaged in CSR initiatives of the companies that practice CSR. Such a desire among the respondents creates the rich soil for the companies to engage their employees in their social initiatives.

19. I will be involved in CSR activities of the company that practices CSR in the nearest future (i.e. the next three months).

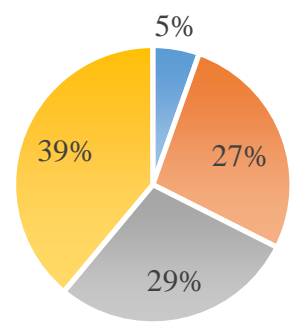

- Disagree

- Neither Agree nor Disagree

- Agree

- Strongly Agree

Figure 19.

Source: Survey Materials 
Figure 19 shows that $39 \%$ of respondents strongly agree with the following statement: "I will be involved in CSR activities of the company that practices CSR in the nearest future and $29 \%$ of them agree to do it. These figures again confirm what is found in the analysis above (see the figures 17 and 18).

20-1. I consider myself loyal to brands that practice corporate social responsibility activities.

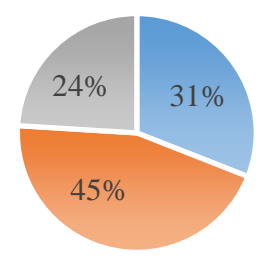

" Neither Agree nor Disagree $\approx$ Agree $\backsim$ Strongly Agree

Figure 20.

Source: Survey Materials

According to the Figure 20, 45\% respondents consider themselves loyal to brands that practice CSR activities. If summing up the percentages of agree and strongly agree categories $(45 \%+24 \%=69 \%)$, the one can conclude that practicing CSR in companies can generate loyalty among customers.

20-2. A brand with strong corporate social responsibility would be my first choice

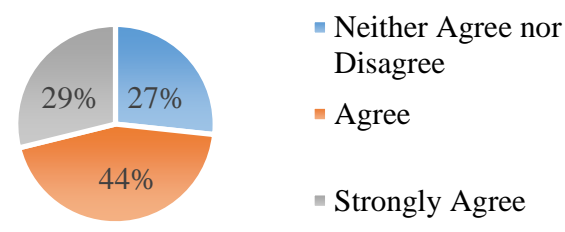

Figure 21.

Source: Survey Materials

20-4. I will not buy other brands if a similar brand that practices corporate social responsibility activities is available.

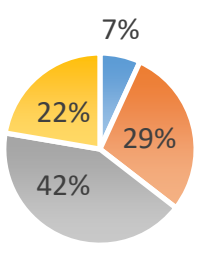

\footnotetext{
- Disagree

- Neither Agree nor Disagree

- Agree

- Strongly Agree
}

Figure 23.

Source: Survey Materials
20-3. A brand with strong corporate social responsibility is seemed as more dependable and keeps customers interest in mind

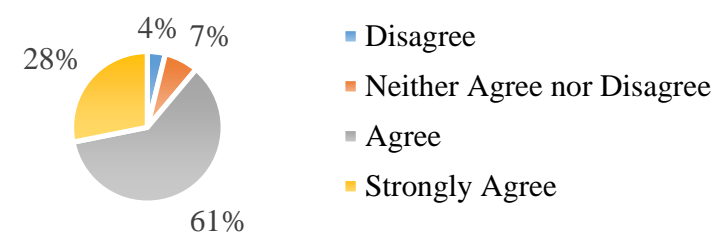

Figure 22.

Source: Survey Materials

20-5. Corporate social responsibility activities increase the level of trust you have in a brand

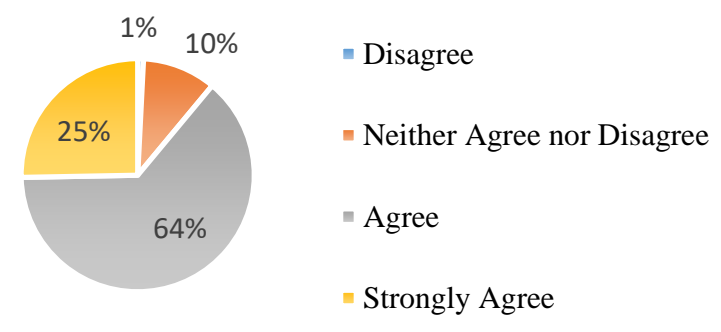

Figure 24.

Source: Survey Materials 
20-6. I view companies that practice corporate social responsibility in a more positive manner

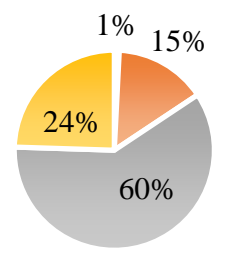

$$
\begin{aligned}
& \text { — Disagree } \\
& \text { - Neither Agree nor Disagree } \\
& \text { — Agree } \\
& \text { " Strongly Agree }
\end{aligned}
$$

Figure 25.

Source: Survey Materials

Based on the respondents' responses to the statements given above (see the Figures from 21 to 25), the one can conclude that companies' efforts to initiate the programs having the positive social consequences not only generate the customer loyalty toward them but these companies are perceived as top of mind brands that customer considers first when purchasing the needed items. At the same time, customers believe that companies with strong corporate social responsibility are more dependable and customer oriented, even more trustworthy and likable than those companies that don't have such a practice.

20-7. I would willingly pay price premiums to the companies that practice corporate social responsibility.
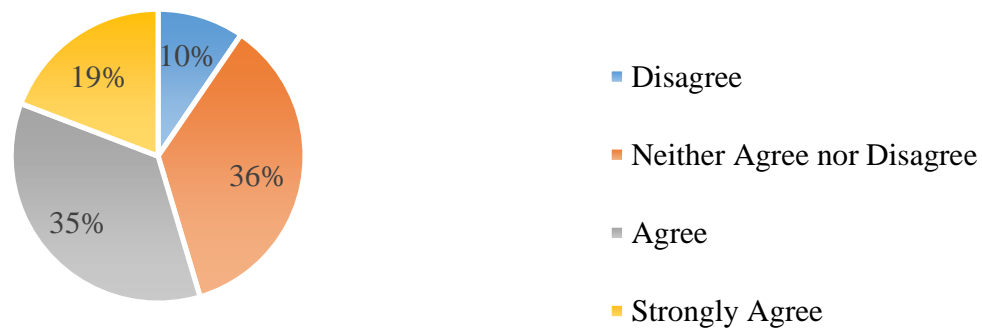

Figure 26.

Source: Survey Materials

$35 \%$ of respondents agree and $19 \%$ strongly agree to the statement "I would willingly pay price premiums to the companies that practice CSR" but since the price for the majority of respondents is very crucial, $36 \%$ of respondents chose the neutral positions.

21. A-D. If several companies make the same products, how important are the following for deciding which one to buy? (Check one for each)
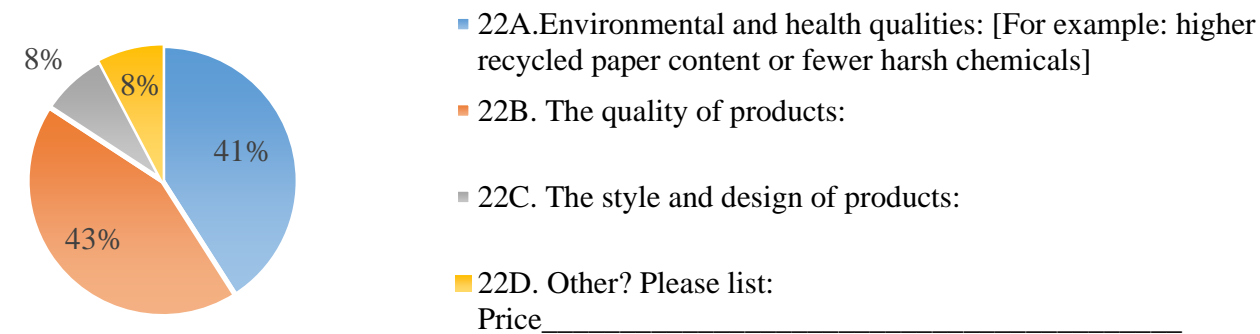

Figure 27.

Source: Survey Materials 
Figure 27 indicates that environmental issues and quality of products are two main factors that guide the respondent's choices.

22. Please, rank the companies from which You would prefer to buy products/services using the scale ranging from 1 to 12 by assigning 1 point to the company that is the most preferable to You and 12 points to the company that is the least preferable to You.

Table 4.

\begin{tabular}{lll}
\hline CSR Arrange & Total & $\begin{array}{l}\text { Overall } \\
\text { Ranking }\end{array}$ \\
\hline Company that treats employees with respect & 5228 & 7 \\
Company that employee's people with disabilities & 4333 & 12 \\
Company that performs better than the law(s) demand(s) & 5060 & 10 \\
Company that follows legal requirements & 4822 & 11 \\
Company that employee's people & 5316 & 6 \\
Company that sets a higher ethical standard & 5145 & 9 \\
Company that gets involved in social campaigns & 5156 & 8 \\
Company that pays taxes & 6631 & 3 \\
Company that offers good quality products & 6128 & 4 \\
Company that helps to build a better society for all & 6043 & 5 \\
Company that makes a profit & 6671 & 2 \\
Company that is environmentally friendly & 6703 & 1 \\
\hline
\end{tabular}

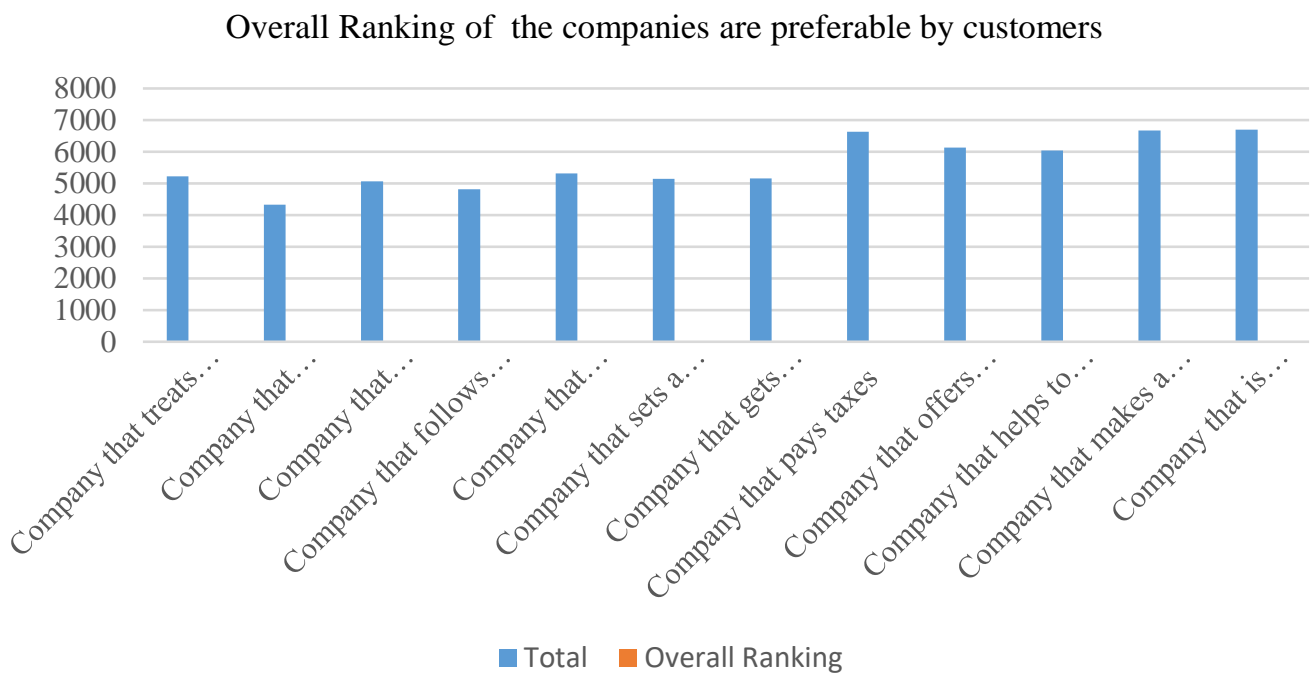

Figure 28.

Source: Survey Materials

According to the Table 4, the first of top six priorities among respondents are: company that is environmentally friendly (Rank 1), company that makes profit (Rank 2), company that pays the taxes (Rank 3), company that offers good quality products (Rank 4), company that helps to build a better society for all (Rank 5), company that employee's people (Rank 6).

As it is obvious from the responses of respondents, treatment of employees with respect and the deployment of high ethical standards by the companies in their business conduct as well as the adherence to legal requirements received relatively lower scores, perhaps because respondents don't understand the comprehensive nature of CSR yet - what it is about and what it stands for. It is clear from their responses to the first two questions. The creation of 
the knowledge of CSR among society members can generate more trust, respect and loyalty toward the companies practicing the ethical behavior in all directions.

23. Please, arrange the following customer needs you think the corporations must meet in an ascending order using the scale ranging from 1 to 11 , where 1 means "the most important" and 11 means - "the least important":

Table 5.

\begin{tabular}{|c|c|c|}
\hline Customer needs & Total & $\begin{array}{l}\text { Overall } \\
\text { Ranking }\end{array}$ \\
\hline $\begin{array}{l}\text { Customer needs for healthy environment (better pollution controls, and } \\
\text { more energy-efficient operations) }\end{array}$ & 6443 & 2 \\
\hline $\begin{array}{l}\text { Customer needs for Value Marketing - offering financially cautious buyers } \\
\text { greater value - the right combination of quality and service at a fair price }\end{array}$ & 6135 & 5 \\
\hline $\begin{array}{l}\text { Customer needs for environmental sustainability - meeting present needs } \\
\text { without compromising the ability of future generations to meet their needs }\end{array}$ & 6632 & 1 \\
\hline Customer needs in high quality of products, modern style and design & 5989 & 6 \\
\hline $\begin{array}{l}\text { Customer needs for more environmentally responsible products } \\
\text { (production of recyclable or biodegradable packaging, biodegradable } \\
\text { bottles, plastics, and other packaging materials ) }\end{array}$ & 6389 & 4 \\
\hline Empathizing with the customer during purchasing time & 5792 & 7 \\
\hline Customer needs for being friendly and warm during purchasing time & 5506 & 11 \\
\hline $\begin{array}{l}\text { Customer needs for safety of products - reducing the quantity of chemical } \\
\text { pollutants (micro-and Nano plastics) in food supply; }\end{array}$ & 6393 & 3 \\
\hline Customer needs for treating the customer fairly during purchasing time & 5753 & 8 \\
\hline $\begin{array}{l}\text { Customer needs for offering multiple options and several alternatives } \\
\text { during purchasing time }\end{array}$ & 5715 & 9 \\
\hline Customer needs for being honest and sincere during purchasing time & 5607 & 10 \\
\hline
\end{tabular}

Customer needs which the corporations must meet

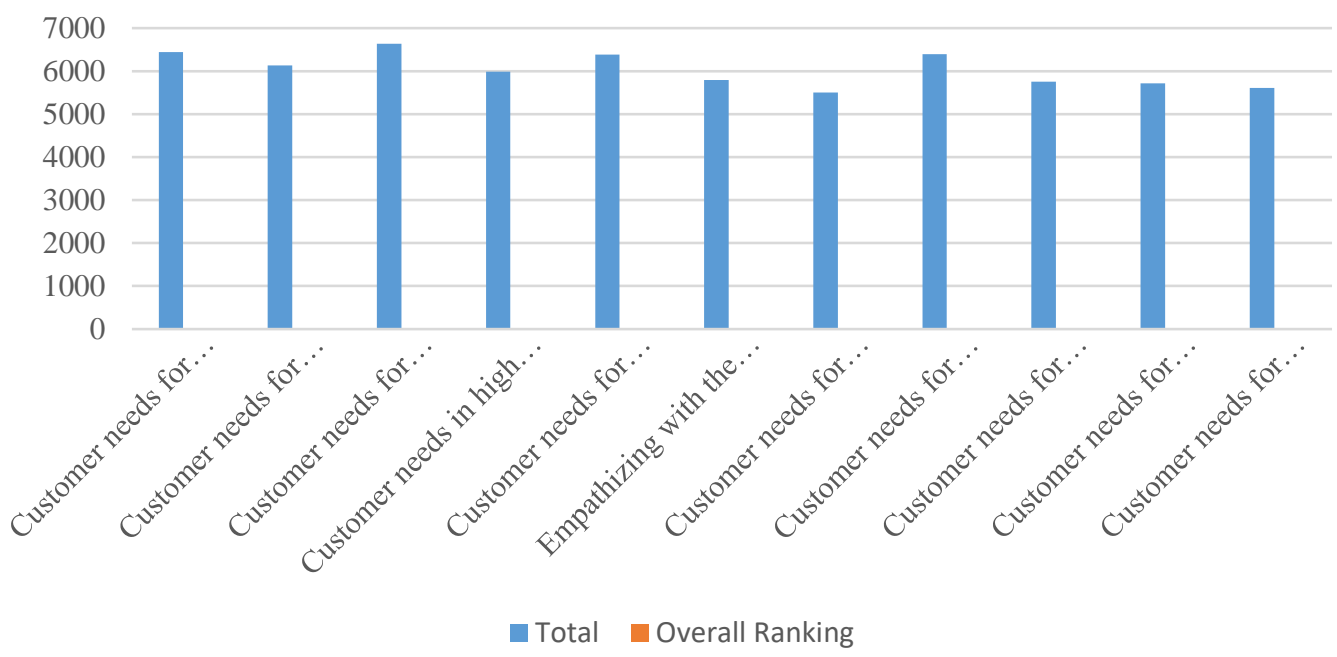

Figure 29.

Source: Survey Materials 
Based on the Table 5, the first of top six needs that the companies must meet are the following: customer needs for environmental sustainability - meeting present needs without compromising the ability of future generations to meet their needs (Rank 1), needs for healthy environment (better pollution controls, and more energy-efficient operations) (Rank 2), needs for safety of products - reducing the quantity of chemical pollutants (micro-and Nano plastics) in food supply (Rank 3), customer needs for more environmentally responsible products (production of recyclable or biodegradable packaging, biodegradable bottles, plastics, and other packaging materials) (Rank 4), customer needs for Value Marketing offering financially cautious buyers greater value - the right combination of quality and service at a fair price (Rank 5), customer needs in high quality of products, modern style and design (Rank 6). Survey results indicate that corporations must concentrate more of their efforts on the long-term needs of society at the same time not neglecting its short term requirements like customer needs for treating them fairly during purchasing time as well as offering them multiple options of products and services. These results also serve as an additional prove to the findings obtained from the previous question placing the care over environment among the first priorities for customers. The list of customer requirements toward the corporations will be enlarged in the future as the knowledge of CSR will be deepened among customers and that would result in corresponding changes in their priorities.

24. How likely are You to favorably evaluate the company that practices CSR?

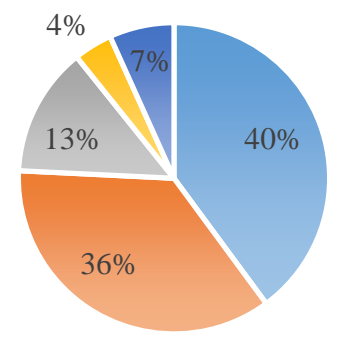

$$
\begin{aligned}
& \text { - Very likely } \\
& \text { - Somewhat Likely } \\
& \text { - Neither Likely nor Unlikely } \\
& \text { - Unlikely } \\
& \text { - Very Unlikely }
\end{aligned}
$$

Figure 30.

Source: Survey Materials

According to the Figure 30, 40\% of respondents are very likely and 36\% somewhat likely to favorably evaluate the company that practices CSR. The obtained results serve as a signal for the companies that refrain from using CSR when conducting the business.

25. How likely are You to purchase product from the company that practices CSR?

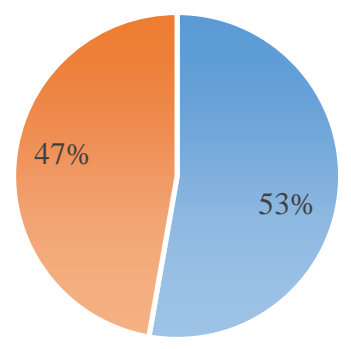

Figure 31.

Source: Survey Materials 
As it was expected from the above answers provided by the respondents, all of them expressed the readiness to purchase products from those companies that practices CSR. As it is clear from the responses, 53\% of them are "very likely" to buy the products from the companies that care about society. If generalizing the study findings to the total population using $95 \%$ confidence interval, it can be said that from $49 \%$ to $56 \%$ of population is" very likely" to buy the products from companies initiating the programs that have positive impact on society.

26. Would you be influenced in your purchasing if you were aware that company cares about environment?

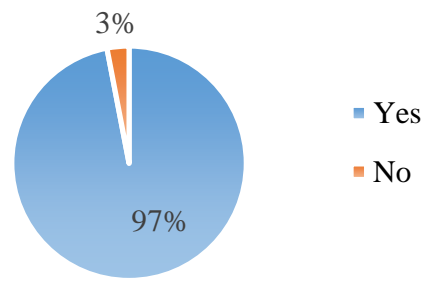

Figure 32.

Source: Survey Materials
27. I am positive towards purchasing products from the company engaged in

CSR:

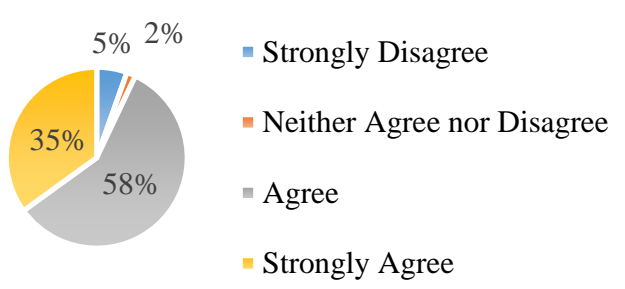

Figure 33.

Source: Survey Materials

28. I have the intention to purchase products from the company that practices CSR:

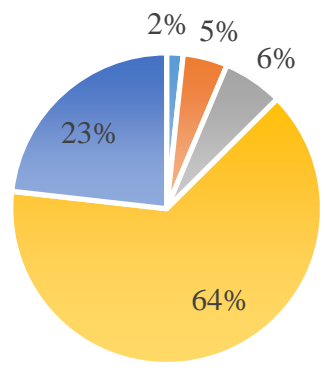

" Very Unlikely $\quad$ - Unlikely
" Neutral $\quad$ - Likely
" Very Likely

Figure 34.

Source: Survey Materials

To have a more accurate resolution for questions \#24 and \#25, respondents were asked three more precise questions \#26, \#27 and \#28. The first question was developed to understand if the knowledge about companies' environmental activities would have an influence on respondents purchase decisions. $97 \%$ of respondents determinately answered "yes". $58 \%$ of respondents agree, and $35 \%$ of respondents strongly agree to purchase products from those companies engaged in CSR. These answers are in compliance with the answers received to the question \#24. In response to the question \#28, 87\% $(64 \%+23 \%=87 \%)$ of respondents expressed their readiness to purchase products from those companies that practices CSR. Obtained results create the rich motivation for the companies to practice CSR. 
29. How likely are You to pay price premiums to the company engaged in CSR?

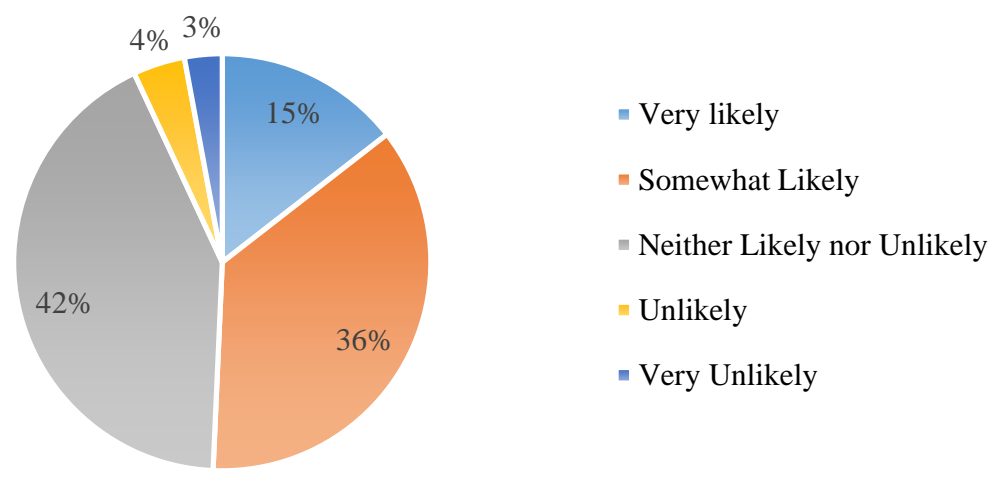

Figure 35.

Source: Survey Materials

Figure 35 reveals that $15 \%$ of respondents are "very likely" and $36 \%$ are "somewhat likely" to pay price premiums to the companies engaged in CSR. If taking into account that more people are price sensitive, this result is not surprising at all. However, it does not mean at all that companies must cease their care about people and environment in which they operate. As always, the burden of premium prices lies on affluent people, those with abundant resources to whom the healthy environment is essential.

The results of the relationships between variables under study have been arranged in the table below:

Table 6.

The Results of Multiple Regressions

\begin{tabular}{llllll}
\hline \multirow{2}{*}{ Model } & \multicolumn{2}{l}{$\begin{array}{l}\text { Unstandardized } \\
\text { Coefficients }\end{array}$} & \multicolumn{2}{l}{$\begin{array}{l}\text { Standardized } \\
\text { Coefficients }\end{array}$} & Sig. \\
\cline { 2 - 4 } & B & Std. Error & Beta & \multirow{2}{*}{ Sige } \\
\hline (constant) & 0.69 & 0.116 & & 0.000 \\
Trustworthiness & 0.135 & 0.052 & 0.138 & 0.778 & 0.010 \\
$\begin{array}{l}\text { Customer willingness to be involved in } \\
\text { CSR initiatives }\end{array}$ & 0.335 & 0.052 & 0.37 & 3.514 & 0.000 \\
Purchase intention & 0.173 & 0.049 & 0.215 & 1.86 & 0.000 \\
\hline
\end{tabular}

Based on figures given in the Table 6, the significant correlations are revealed between the variables of interest: customer CSR awareness and company trustworthiness (the significance is 0.01), CSR awareness and customers' willingness to be engaged in companies' CSR initiatives (significance is 0.000), and customer CSR awareness and customers' intention to buy the product (significance is 0.000 ).

\section{Conclusions}

The main findings of this study is that the level of CSR awareness among Georgian consumers is not high. They have just basic knowledge about CSR and their perception of CSR is rlated mostly to environmental activities. Different aspects of CSR initiatives are hidden among them.

On the other hand, Georgian consumers seem to be concerned with corporations CSR initiatives but their knowledge of CSR is somehow limited with care over environment because they understand this aspect of corporate social responsibility better than other ones.. 
At the same time, customers tend to consider personal benefits they receive from the quality and price of products and services rather than the benefits gained from the ethical and social responsible behavior of corporations when making their purchase decisions. This finding is in line with the study of Becker-Olsen et al. (2006) which found that although CSR is an important attribute of corporate image that attracts consumers, it is not likely that this attribute will automatically be taken into account when personal purchasing decisions are made.

There is also a sort of skeptisime among Georgian consumers in their views of corporate motivations for supporting social initiatives. This skepticism happens since consumers see that numerous companies got failure to present satisfactory verification of their commitments (Beckmann 2007; Elving 2010), and social activities are essentially spurred by corporate selfinterest (Webb \& Mohr 1998). This happen due to the lack of customers ${ }^{6}$ access to companies CSR reports and the failor from the side of corporations to invove customers in planning of their social initiatives.

The results of this study revealed that companies should increase the awareness of their CSR activities in order to raise the trustworthiness among their customers and in this way to influence customers' purchase decisions and their involvement in CSR initiatives.

This particular study serves as an additional prove to the already proliferated and established belief that if corporations want to achieve their targets, they have to integrate CSR in their core business strategies and effectively communicate them to their customers.

This study contributes a valuable basis for further studies into the moderating effect of customer CSR awareness on corporate credibility, particularly in the context of developing country. The findings also have practical inference that provide potential directions for companies to more effectively set and apply their CSR activities to make differential advantage and maximize business returns.

\section{References}

Becker-Olsen, K. L., Cudmore, B. A., \& Hill, R. P. (2006). The impact of perceived corporate social responsibility on consumer behavior. Journal of business research, 59(1), 46-53. https://doi.org/10.1016/j.jbusres.2005.01.001

Beckmann, S. C. (2007). Consumers and corporate social responsibility: Matching the unmatchable?. Australasian Marketing Journal (AMJ), 15(1), 27-36. https://doi.org/10.1016/S1441-3582(07)70026-5

Berens, G., Van Riel, C. B., \& Van Rekom, J. (2007). The CSR-quality trade-off: When can corporate social responsibility and corporate ability compensate each other?. Journal of Business Ethics, 74(3), 233-252. https://doi.org/10.1007/s10551-006-9232-0

Brammer, S. and Millington, A. (2005) Corporate Reputation and Philanthropy-An Empirical Analysis. Journal of Business Ethics, 61, 29-44. http://dx.doi.org/10.1007/s10551-0057443-4

Brown, T. J., \& Dacin, P. A. (1997). The company and the product: Corporate associations and consumer product responses. Journal of marketing, 61(1), 68-84. https://doi.org/10.1177/002224299706100106

Du, S., Bhattacharya, C. B., \& Sen, S. (2007). Reaping relational rewards from corporate social responsibility: The role of competitive positioning. International journal of research in marketing, 24(3), 224-241. https://doi.org/10.1016/j.ijresmar.2007.01.001 
Du, S., Bhattacharya, C. B., \& Sen, S. (2010). Maximizing business returns to corporate social responsibility (CSR): The role of CSR communication. International journal of management reviews, 12(1), 8-19. https://doi.org/10.1111/j.1468-2370.2009.00276.X

Lichtenstein, D. R., Drumwright, M. E., \& Braig, B. M. (2004). The effect of corporate social responsibility on customer donations to corporate-supported nonprofits. Journal of marketing, 68(4), 16-32. https://doi.org/10.1509/jmkg.68.4.16.42726

Sen, S., \& Bhattacharya, C. B. (2001). Does doing good always lead to doing better? Consumer reactions to corporate social responsibility. Journal of marketing Research, 38(2), 225-243. https://doi.org/10.1509/jmkr.38.2.225.18838

Taneja, S. S., Taneja, P. K., \& Gupta, R. K. (2011). Researches in corporate social responsibility: A review of shifting focus, paradigms, and methodologies. Journal of Business Ethics, 101(3), 343-364. https://doi.org/10.1007/s10551-010-0732-6

Webb, D. J., \& Mohr, L. A. (1998). A typology of consumer responses to cause-related marketing: From skeptics to socially concerned. Journal of public policy \& marketing, 17(2), 226-238. https://doi.org/10.1177/074391569801700207 